\section{Thymol and Acetic Acid Vapors Reduce Postharvest Brown Rot of Apricots and Plums}

\author{
W.T. Liu and C.L. Chu ${ }^{1}$ \\ Department of Plant Agriculture, University of Guelph, 4890 Victoria Avenue \\ N., Vineland Station, Ontario LOR 2E0, Canada
}

\section{T. Zhou \\ Agriculture \& Agri-Food Canada, Food Research Program, 93 Stone Road W., Guelph, Ontario N1G 5C9, Canada}

\section{Additional index words. Prunus armeniaca, Prunus salicina, Monilinia fructicola, fumigation}

\begin{abstract}
Fumigation with $1 \mathrm{mg} \cdot \mathrm{L}^{-1} \mathrm{of}$ thymol vapor retarded mycelial growth of Monilinia fructicola (G. Wint.) Honey. Mean colony diameter was reduced from $49 \mathrm{~mm}$ in the control to $13 \mathrm{~mm}$ when the conidia were cultured on potato dextrose agar. Fumigation of apricots (Prunus armeniaca L.) with $2 \mathrm{mg} \cdot \mathrm{L}^{-1}$ of thymol vapor reduced the germination of $M$. fructicola conidia to $2 \%$ compared with $98 \%$ on untreated fruit. Microscopic observations showed that the spores fumigated with thymol were shrunken and had collapsed protoplasts. In in vivo experiments, surface-sterilized apricots and plums (Prunus salicina $\mathbf{L}$.) were inoculated with conidia of $M$. fructicola by applying $20 \mu \mathrm{L}$ of a spore suspension to wounds on the fruit, and then were fumigated with thymol or acetic acid. The incidence of brown rot was reduced to $3 \%$ and $32 \%$ when 'Manch' apricots were fumigated with thymol or acetic acid at $5 \mathrm{mg} \cdot \mathrm{L}^{-1}$, respectively, compared with $64 \%$ incidence in untreated fruit. Fumigation of 'Violette' plums with thymol or acetic acid at $8 \mathrm{mg} \cdot \mathrm{L}^{-1}$ reduced brown rot from $88 \%$ in the control to $24 \%$ and $25 \%$, respectively. Fumigation of 'Veeblue' plums with thymol at $4 \mathrm{mg} \cdot \mathrm{L}^{-1}$ reduced brown rot from $56 \%$ in the control to $14 \%$. Fumigation of apricots with thymol resulted in firmer fruit and higher surface browning, but total soluble solids and titratable acidity were not affected. Fumigation of plum with thymol resulted in higher total soluble solids, but firmness and titratable acidity were not affected. Thymol fumigation caused phytotoxicity on apricots but not on plums.
\end{abstract}

Apricots and plums are quite susceptible to most of the postharvest diseases and disorders affecting stone fruits (Harvey et al., 1972; Snowdon, 1990). Brown rot caused by Monilinia fructicola is one of the most destructive of these diseases (De Vries-Paterson et al., 1991; Jerome, 1958; Michailides and Morgan, 1997). Wells et al. (1994) reported that brown rot was a leading cause of losses in plums (up to $50 \%$ of the disease loss) in their 3-year survey in New York. This organism causes latent infections of the fruit prior to harvest, while in storage, and during transport to market. The presence of $M$. fructicola brown rot can even affect the processed fruit product (Bosch et al., 1992).

In California, fungicides such as benomyl, iprodione, and triforine were registered for the postharvest treatment of stone fruits to control brown rot until 1996 (Feliciano et al., 1992; Smilanick et al., 1993). Benomyl can no longer be used because of a resistance problem. Rh ônePoulenc Ag. Co. voluntarily withdrew iprodione for postharvest use in 1996 (Adaskaveg and Michailides, 1996). Since

Received for publication 13 Nov. 2000. Accepted for publication 6 May 2001. We thank R. Tsao, K.E. Schneider, and T. Larmet for technical assistance; and C. Chong and A.M. Svircev for critical review of the manuscript.

${ }^{1}$ To whom reprint requests should be addressed. E-mail address: gchu@uoguelph.ca then the stone fruit industry in California has had no fungicides specifically registered for the control of postharvest brown rot. Similarly, registered fungicides are not available for the Ontario fruit industry to control this disease.

In recent years, several alternatives to the chemical control of postharvest decay of stone fruits have emerged. These include: treating with hot water mixed with $10 \%$ alcohol (Margosan et al., 1997), fumigating with natural volatiles (Sholberg et al., 1996), using ultraviolet light (Stevens et al., 1996), calcium salts (Biggs et al., 1997), sugar analogs (El Ghaouth et al., 1995), and biological control agents (Falconi and Mendgen, 1994; Smilanick, 1994; Smilanick et al., 1993; Wilson and Wisniewski, 1989; Wilson et al., 1991; Zhou et al., 1999).

Sholberg and Gaunce (1995) demonstrated that the postharvest application of low concentrations of acetic acid vapor were extremely effective for the control of Botrytis cinerea Pers. on apples (Malus $\times$ domestica Borkh.), with no induced phytotoxicity. In addition, acetic acid was an effective postharvest fumigant, which destroyed fungal spores on peaches (Prunus persica L.), apricots, and cherries (Prunus avium L.) (Sholberg and Gaunce, 1996). Fumigation with acetic acid, followed by the use of modified atmosphere packaging (MAP) and storage at $0{ }^{\circ} \mathrm{C}$, reduced the per- centage of decayed grapes (Vitis vinifera L.) from $94 \%$ in the control to $2 \%$ (Moyls et al., 1996). Formic acid, propionic acid, and aldehydes also have been effectively applied as vapor phase fumigants for the control of postharvest decay in cherries (Mattheis and Roberts, 1993; Sholberg, 1998).

Essential oils are volatile compounds produced in many plant species. These oils are thought to play a role in plant defense mechanisms against phytopathogenic microorganisms (Mihaliak et al., 1991). Essential oil from Thymus capitatus (thyme) displayed antifungal activity on stored food commodities (Mishra, 1994) and inhibited the growth of both $B$. cinerea and $M$. fructicola (Arras et al., 1995; Tsao and Zhou, 2000). The potential of using essential oils by spraying or dipping techniques to control postharvest decay has been examined in vegetables, fruits, and cut flowers (Dixit et al., 1995; Smid et al., 1994; Tiwari et al., 1988). Fumigation of sweet cherries with thymol was effective in controlling postharvest gray mold rot caused by $B$. cinerea (Chu et al., 1999) and brown rot caused by $M$. fructicola (Chu et al., 2001). Fumigation with thymol at $30 \mathrm{mg} \cdot \mathrm{L}^{-1}$ followed by MAP and storage at $0{ }^{\circ} \mathrm{C}$ reduced the incidence of gray mold rot from $35 \%$ in untreated fruit to $0.5 \%$.

The objectives of this research were to determine: 1) the effects of thymol vapor on conidial germination and mycelial growth of M. fructicola; 2) the optimum fumigation dosage of acetic acid and thymol for maximum brown rot control with minimum phytotoxicity to apricots and plums; and 3) the effects of fumigation on fruit firmness, total soluble solids, and titratable acidity.

\section{Materials and Methods}

Fruits. 'Harglow' and 'Manch' apricots and 'Violette' and 'Veeblue' plums were handpicked from the experimental farm of the Dept. of Plant Agriculture, Univ. of Guelph (Vineland Station, Ont.), during summer 1999 and stored at $1{ }^{\circ} \mathrm{C}$. The fruits were surfacesterilized with $300 \mathrm{mg} \cdot \mathrm{L}^{-1}$ of sodium hypochlorite solution for $60 \mathrm{~s}$, rinsed twice in sterile distilled water, and placed individually on a laboratory bench in an aseptic walk-in cooler before inoculation and fumigation treatments.

Pathogen. The strain of Monilinia fructicola used in these experiments was originally isolated from a peach fruit with brown rot, and cultured on potato dextrose agar (PDA, Difco Ltd., Detroit) for 7 to $10 \mathrm{~d}$. Conidial suspensions of M.fructicola were prepared by scraping conidia from the fungal colony surface with a sterile loop and suspending them in sterile water in a screw-capped test-tube. The concentration of conidia for each test was determined using a hemacytometer (American Optical Corp., Buffalo, N.Y.).

In vitro fumigation of $M$. fructicola with thymol vapor. Monilinia fructicola grown on PDA plates in sealed glass jars were fumigated to determine whether thymol vapor could affect the growth of the fungus. A plug $(5 \times 5$ $\mathrm{mm})$ cut from a PDA plate colonized by $M$. fructicola was transferred onto fresh PDA in a 
plastic petri dish $(5.5 \mathrm{~cm}$ in diameter $)$. The petri dish was then placed on the bottom of a 2-L glass jar. To introduce thymol into the glass jars, one piece of filter paper $(4.0 \mathrm{~cm}$ in diameter) was attached on the inner-side of each jar lid with a short length of cellophane tape. Thymol (5-methyl-2-isopropylphenol, Sigma Chemical Co., St. Louis) was dissolved in $95 \%$ ethanol (HPL grade; Sigma Chemical Co.) and four concentrations, i.e., 0, 10, 300, and $1000 \mathrm{~g} \cdot \mathrm{L}^{-1}$, of thymol-ethanol solutions were prepared. Ethanol was used as a solvent in this study to dissolve and vaporize thymol. The thymol solutions $(200 \mu \mathrm{L} / \mathrm{jar})$ were applied on the filter paper with a gastight syringe $(1000 \mu \mathrm{L})$. The lid was tightly screwed on the mouth of the jar immediately after application of the thymol solution. Four thymol concentrations $\left(0,1,30\right.$, and $\left.100 \mathrm{mg} \cdot \mathrm{L}^{-1}\right)$ were established in the jars as four treatments. A blank control of neither thymol nor ethanol was also used to distinguish the possible effect from ethanol. There were three replicates for each treatment. Two temperatures with different incubation periods were used: 1) $10^{\circ} \mathrm{C}$ for 28 $\mathrm{d}$ and 2) $6^{\circ} \mathrm{C}$ for $60 \mathrm{~d}$. At the end of each incubation period, the colony diameters of $M$. fructicola were measured to assess the effectiveness of thymol fumigation on the growth of the pathogen.

Inoculation of fruits. Inoculation, similar to the procedure used by Hong et al. (1998), was performed in a sterilized walk-in cooler with a contamination-control air filtration system soon after the fruits were surface-sterilized. A stainless steel rod (4 $\mathrm{mm}$ in diameter) with a nail-like point was used to wound each fruit by puncturing to a depth of $5 \mathrm{~mm}$. Two wounds were made on opposite sides of each fruit. Twenty microliters of a water suspension of $M$. fructicola at $1 \times 10^{4}$ conidia/mL were applied to each wound and allowed to air-dry for $3 \mathrm{~h}$. There were three replicates for each treatment. Each replicate consisted of 15 apricots or 12 plums.

Fumigation and incubation of fruits. Five experiments were conducted in which thymol or acetic acid was used to treat apricots or plums. The fumigant consisted of 0 to 10 $\mathrm{mg} \cdot \mathrm{L}^{-1}$ of thymol or glacial acetic acid (HPLC grade, minimum $99.7 \%$; Caledon Laborato-

Table 1. Colony diameter of Monilinia fructicola grown on PDA plates in glass jars with thymol at $6^{\circ} \mathrm{C}$ for $60 \mathrm{~d}$ or $10^{\circ} \mathrm{C}$ for $28 \mathrm{~d}$.

\begin{tabular}{lcc}
\hline \hline & \multicolumn{2}{c}{ Colony diam $(\mathrm{mm})$} \\
\cline { 2 - 3 } Thymol $^{\mathrm{z}}\left(\mathrm{mg} \cdot \mathrm{L}^{-1}\right)$ & \multicolumn{2}{c}{ Incubation temp/period } \\
\cline { 2 - 3 } 6 $^{\circ} \mathrm{C}$ for $60 \mathrm{~d}$ & $10^{\circ} \mathrm{C}$ for $28 \mathrm{~d}$ \\
\hline Blank control $^{\mathrm{y}}$ & $48.0 \mathrm{a}^{\mathrm{x}}$ & $55.0 \mathrm{a}$ \\
$0^{\mathrm{w}}$ & $49.3 \mathrm{a}$ & $54.3 \mathrm{a}$ \\
1 & $12.7 \mathrm{~b}$ & $19.3 \mathrm{~b}$ \\
10 & $0.0 \mathrm{c}$ & $0.0 \mathrm{c}$ \\
30 & $0.0 \mathrm{c}$ & $0.0 \mathrm{c}$ \\
Significance & $* *$ & $* *$ \\
\hline
\end{tabular}

${ }^{2}$ Prepared with $100 \mu \mathrm{L} \cdot \mathrm{L}^{-1}$ ethanol.

${ }^{y}$ Neither thymol nor ethanol was used.

${ }^{\mathrm{x}}$ Means within a column by the same letter are not significantly different at $P \quad 0.05$ according to Duncan's multiple range test.

${ }^{\text {w}}$ Only ethanol was used.

** Significant at $P \quad 0.01$. ries Ltd., Georgetown, Ont., Canada) depending on the experiment. The inoculated fruits were individually placed on a metal net in an aluminum tray, and then were fumigated in a 260-L gastight chamber. The required amount of fumigant was placed in a small aluminum cup. The cup was connected to a heating element (6 $\mathrm{mm}$ in diameter), which was a 30 $\mathrm{W}$ soldering iron, and located in front of a small fan $(32 \mathrm{~W}, 15 \mathrm{~cm}$ in diameter) on the bottom of the fumigation chamber. The chamber was sealed after the inoculated fruit were placed on a grill rack above the fan. The iron and the fan were turned on simultaneously to vaporize and circulate the thymol or acetic acid vapor inside the chamber. After $10 \mathrm{~min}$ the iron was turned off and the fan was kept running for an additional 10 min until the chamber was opened. The fruit were removed from the chamber and incubated at 10 or $18{ }^{\circ} \mathrm{C}$ for 3 to $8 \mathrm{~d}$, depending on the development of brown rot.

Determination of germination and morphology of thymol-fumigated conidia of $M$. fructicola. A germination test and morphological observations were conducted to determine the effects of thymol vapor on the conidia of M. fructicola. In the germination test, apricots inoculated with conidia of $M$. fructicola were incubated at $18^{\circ} \mathrm{C}$ for $4 \mathrm{~d}$ to allow brown rot symptoms to develop. The decayed fruits exhibiting sporulation structures were then fumigated with $0,2,4,6$, and $8 \mathrm{mg} \cdot \mathrm{L}^{-1}$ of thymol. To determine conidial germination, conidial suspensions were prepared by scraping conidia from individual apricots from each fumigation treatment, and adjusted to a concentration of $1 \times 10^{4}$ conidia/mL using a hemacytometer. Three conidial suspensions (replicates) were prepared for each treatment. Twenty microliters of the suspension were placed on a water agar plug $(1.5 \times 1.5 \mathrm{~cm}$ in size) on a glass slide. The plug-slides were kept in petri dishes lined with moistened filter paper and incubated at $22^{\circ} \mathrm{C}$ for $20 \mathrm{~h}$. Conidial germination was determined under a compound microscope $(10 \times 20$ magnification $)$. For morphological observations, conidia were scraped from fumigated apricots into drops of distilled water, mounted on glass slides, and observed with a compound microscope $(10 \times$ 20 magnification) for morphological changes. The observations were recorded using an image analyzer (Camera HV-C2OM, Hitachi, Japan; Image Station Program KS400V2.00).

Evaluation of disease incidence and fruit quality. At the end of the incubation period, disease incidences on apricots and plums were determined by counting the number of wounds showing typical brown rot symptoms. The severity of phytotoxicity was evaluated by estimating the percentage of browning area on the fruit surface for each apricot. Then, the healthy fruits or uninfected portions of the decayed fruit were used for quality analysis. Firmness was measured with a Voland texture analyzer equipped with a 1.5 -mm-diameter plunger at a speed of $2.0 \mathrm{~mm} \cdot \mathrm{s}^{-1}$ for a $5-\mathrm{mm}$ distance. Two firmness readings were taken from each fruit by puncturing two spots on opposite sides of the healthy fruit or two spots on the possible sites of the uninfected portion of the decayed fruit. Then the undecayed fruit from each replicate were sealed in a plastic bag and stored in a freezer at $-25^{\circ} \mathrm{C}$ until they were further analyzed. The frozen fruit samples were thawed at $4{ }^{\circ} \mathrm{C}$ overnight and then pressed with a manual presser to collect juice samples for determining total soluble solids content and titratable acidity. Total soluble solids content was measured with an Abbe refractometer (model 10450; AOInstruments, Buffalo, N.Y.). Titratable acidity was measured by titrating 2 $\mathrm{mL}$ of juice with a $0.1 \mathrm{~N} \mathrm{NaOH}$ solution to a $8.20 \mathrm{pH}$ endpoint using a Fisher electrometer

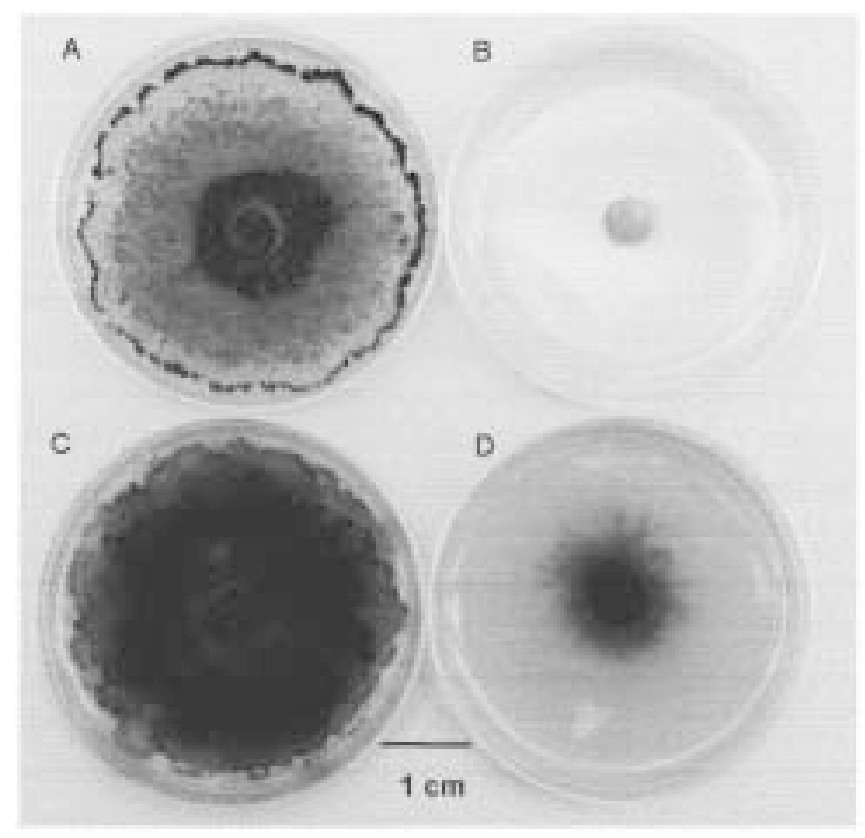

Fig. 1. Mycelial growth of Monilinia fructicola after incubation in a 2-L glass jar at $10^{\circ} \mathrm{C}$ for $28 \mathrm{~d}$ : (A) blank control, incubated without ethanol or thymol; (B) incubated with $10 \mathrm{mg} \cdot \mathrm{L}^{-1}$ thymol plus $100 \mu \mathrm{L} \cdot \mathrm{L}^{-1}$ ethanol; (C) incubated with $100 \mu \mathrm{L} \cdot \mathrm{L}^{-1}$ ethanol; and (D) incubated with $1 \mathrm{mg} \cdot \mathrm{L}^{-1}$ thymol plus $100 \mu \mathrm{L} \cdot \mathrm{L}^{-1}$ ethanol. 
and dispenser (models 380 and 395, respectively; Fisher Scientific, Ottawa, Ont.). In addition, after the firmness test, a sensory test by five panelists with prior experience in fruit evaluation was conducted for the 'Veeblue' plums. The panelists were asked to judge the fresh fruit by viewing the integrity and color, and tasting the flavor and texture. Plums from each treatment were placed in a precoded plate for assessment and all plates were randomly arranged. The score sheets were graded according to the following scale: $0=$ disintegrated or flaccid for visual integrity, pale purple for color, absence of plum flavor (or presence of off-flavor) for flavor, excessively soft for texture; and $9=$ natural plum shape for visual integrity, dark purple for color, strong plum flavor for flavor, and preferable firmness for texture.

Data analysis. Completely randomized designs were used for all experiments. Data were transformed to logit scale for the statistical analysis of the percent brown rot and percent browning. Statistical analysis was carried out with PROC GLM (SAS Institute, Cary, N.C.). Means were separated by Duncan's multiple range test when the analysis of variance showed statistical significance $\left(\begin{array}{ll}P & 0.05\end{array}\right)$. PROC REG and PROC GENMOD were used for linear and nonlinear regression analyses. Linear regression lines and nonlinear regression curves were fitted to data from studies on thymol or acetic acid concentrations.

\section{Results}

Effect of thymol vapor on mycelia growth of $M$. fructicola. The average colony diameters of $M$. fructicola grown on PDA at 6 and $10^{\circ} \mathrm{C}$ were reduced by thymol fumigation, as compared with the ethanol $\left(0 \mathrm{mg} \cdot \mathrm{L}^{-1}\right.$ thymol $)$ and controls with neither thymol nor ethanol (Table 1). After incubation at $6{ }^{\circ} \mathrm{C}$ for $60 \mathrm{~d}$, mean colony diameters were 49 and $13 \mathrm{~mm}$ for the ethanol control and $1 \mathrm{mg} \cdot \mathrm{L}^{-1}$ thymol treatments, respectively. Fumigation with thymol at 10 or $30 \mathrm{mg} \cdot \mathrm{L}^{-1}$ completely prevented colony growth on PDA. Mean colony diameters between the ethanol and the blank controls were not different. This demonstrated that ethanol vapor at $100 \mu \mathrm{L} \cdot \mathrm{L}^{-1}$ alone did not affect the growth of M. fructicola. However, there was more sporulation on the blank control plates than on plates of the ethanol control. Similar results were also found after the samples were incubated at $10^{\circ} \mathrm{C}$ for $28 \mathrm{~d}$ (Fig. 1).

Efficacy of fumigation in brown rot control on apricots and plums. 'Manch' apricots fumigated for $20 \mathrm{~min}$ with thymol or acetic acid at $5 \mathrm{mg} \cdot \mathrm{L}^{-1}$ had $3 \%$ or $32 \%$ brown rot decay, respectively, as compared with $64 \%$ brown rot decay in the nonfumigated control after the fruit were incubated at $18{ }^{\circ} \mathrm{C}$ for $3 \mathrm{~d}$ (Fig. 2). Decay was reduced to $0 \%$ and $2 \%$ when the apricots were fumigated with $10 \mathrm{mg} \cdot \mathrm{L}^{-1}$ of thymol or acetic acid, respectively.

The effectiveness of thymol or acetic acid fumigation was further studied on 'Harglow' apricots at concentrations from 0 to $4 \mathrm{mg} \cdot \mathrm{L}^{-1}$. After the apricots were incubated at $18^{\circ} \mathrm{C}$ for $4 \mathrm{~d}$, fumigating the fruits with 3 or $4 \mathrm{mg} \cdot \mathrm{L}^{-1}$ of

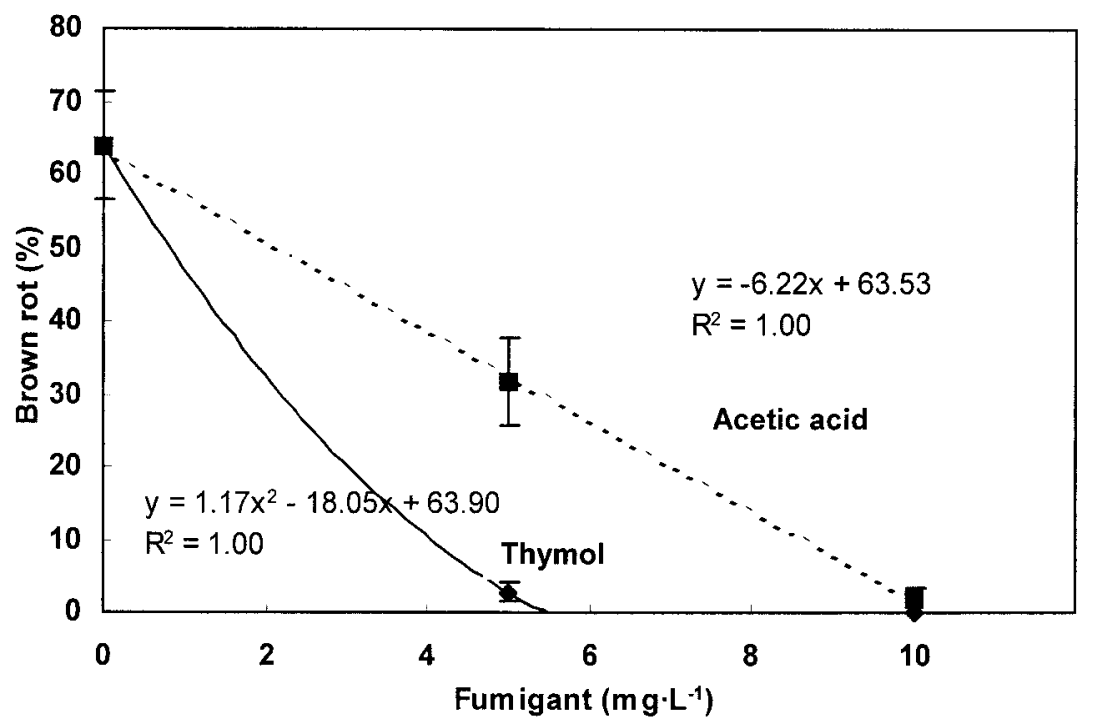

Fig. 2. Brown rot incidence of wounds on 'Manch' apricots after they were inoculated with Monilinia fructicola, fumigated with 5 or $10 \mathrm{mg} \cdot \mathrm{L}^{-1}$ thymol or acetic acid, and incubated at $18^{\circ} \mathrm{C}$ for $3 \mathrm{~d}$. Vertical bars indicate standard errors.

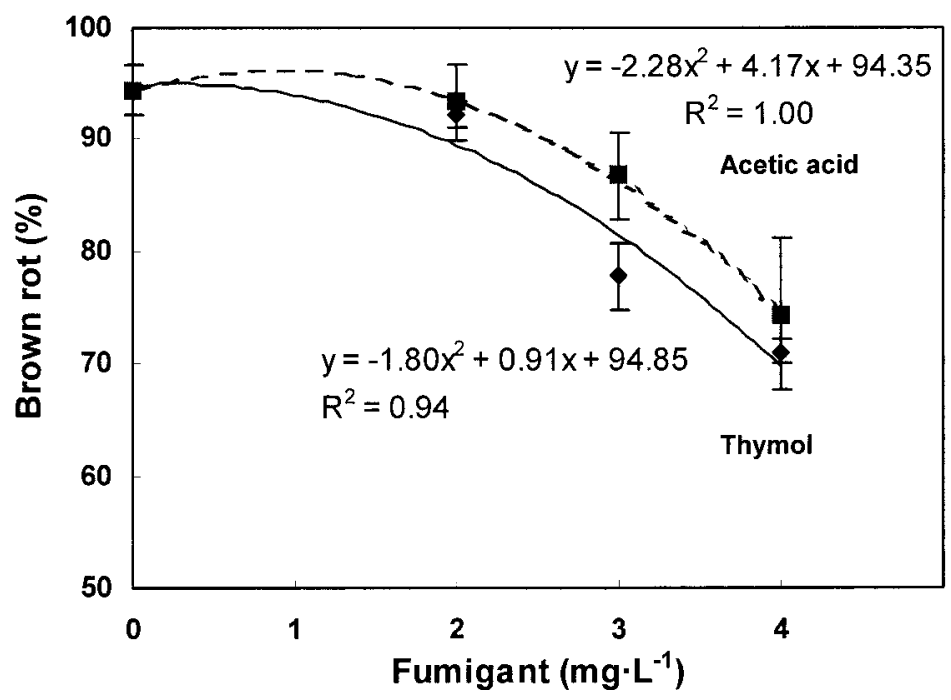

Fig. 3. Brown rot incidence of wounds on 'Harglow' apricots after they were inoculated with Monilinia fructicola, fumigated with $2-4 \mathrm{mg} \cdot \mathrm{L}^{-1}$ thymol or acetic acid for $20 \mathrm{~min}$, and incubated at $18{ }^{\circ} \mathrm{C}$ for $4 \mathrm{~d}$. Vertical bars indicate standard errors.

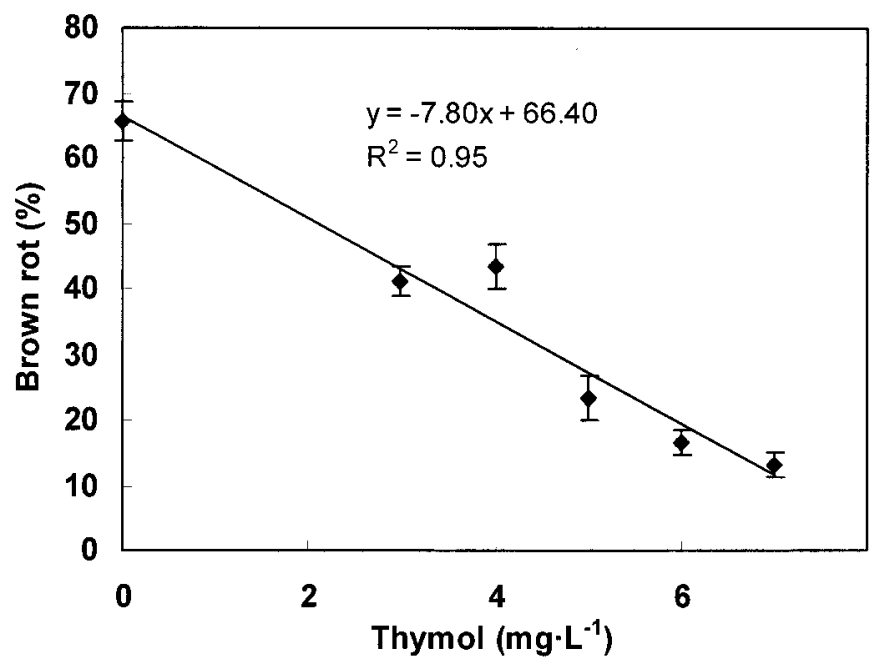

Fig. 4. Brown rot incidence of wounds of 'Harglow' apricots after they were inoculated with Monilinia fructicola, fumigated with $3-7 \mathrm{mg} \cdot \mathrm{L}^{-1}$ thymol for $20 \mathrm{~min}$, and incubated at $10^{\circ} \mathrm{C}$ for $8 \mathrm{~d}$. Vertical bars indicate standard errors. 


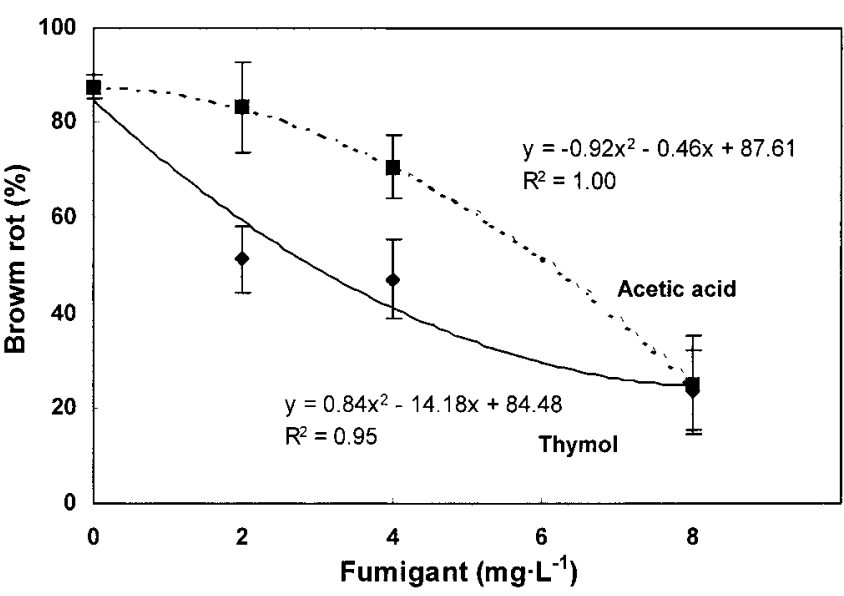

Fig. 5. Brown rot incidence of wounds on 'Violette' plums after they were inoculated with Monilinia fructicola, fumigated with 2,4 , or $8 \mathrm{mg} \cdot \mathrm{L}^{-1}$ thymol or acetic acid for $20 \mathrm{~min}$, and incubated at $18^{\circ} \mathrm{C}$ for $7 \mathrm{~d}$. Vertical bars indicate standard errors.

thymol or $4 \mathrm{mg} \cdot \mathrm{L}^{-1}$ of acetic acid reduced brown rot symptoms (Fig. 3).

The effectiveness of thymol fumigation at 3 to $7 \mathrm{mg} \cdot \mathrm{L}^{-1}$ in controlling brown rot was studied on 'Harglow' apricots (Fig. 4). The incidence of brown rot symptoms was decreased as the concentration of thymol in the fumigation treatment was increased $(\mathrm{y}=66.4$ $\left.-7.8 \mathrm{x}, R^{2}=0.95\right)$. Fumigation with thymol at $7 \mathrm{mg} \cdot \mathrm{L}^{-1}$ reduced brown rot decay from $66 \%$ in the control to $13 \%$ after the apricots were incubated at $10^{\circ} \mathrm{C}$ for $8 \mathrm{~d}$.

After incubation at $18{ }^{\circ} \mathrm{C}$ for $7 \mathrm{~d}$, fumigation of 'Violette' plums with thymol or acetic acid at $8 \mathrm{mg} \cdot \mathrm{L}^{-1}$ reduced the incidence of brown rot to $24 \%$ and $25 \%$, respectively, from $88 \%$ in the control (Fig. 5). Fumigation with acetic acid at 2 or $4 \mathrm{mg} \cdot \mathrm{L}^{-1}$ was not effective in reducing brown rot on plums; however, fumigation with thymol at the same concentrations reduced the incidence of brown rot to $51 \%$ or $48 \%$.

The effectiveness of thymol fumigation was further studied on 'Veeblue' plums at concentrations of 2 to $8 \mathrm{mg} \cdot \mathrm{L}^{-1}$ (Fig. 6). After incubation at $18{ }^{\circ} \mathrm{C}$ for $7 \mathrm{~d}$, the incidence of brown rot of plums fumigated with thymol at $4 \mathrm{mg} \cdot \mathrm{L}^{-1}$ was reduced to $14 \%$ as compared with $56 \%$ observed on non-thymol control samples. Brown rot incidences in 4,6 , or 8 $\mathrm{mg} \cdot \mathrm{L}^{-1}$ thymol-treated fruit were similar. Fumigation with thymol effectively reduced postharvest brown rot on plums and did not cause any appreciable phytotoxicity (Fig. 7).

Effect of thymol vapor on conidial germination and morphology. The percent germination of conidia of $M$. fructicola from fumigated apricots following an incubation period of $20 \mathrm{~h}$ at $22{ }^{\circ} \mathrm{C}$ was reduced by fumigation with thymol (Fig. 8). Only $2 \%$ of the conidia germinated after fumigation with $2 \mathrm{mg} \cdot \mathrm{L}^{-1}$ thymol as compared with $98 \%$ germination in the control samples. Microscopic observation showed that the conidia from thymol-fumigated fruits were shrunken and had abnormal shapes, and their protoplasts were noticeably dehydrated (Fig. 9B) as compared with the nontreated control conidia (Fig. 9A).

Effects of fumigation on fruit quality at-

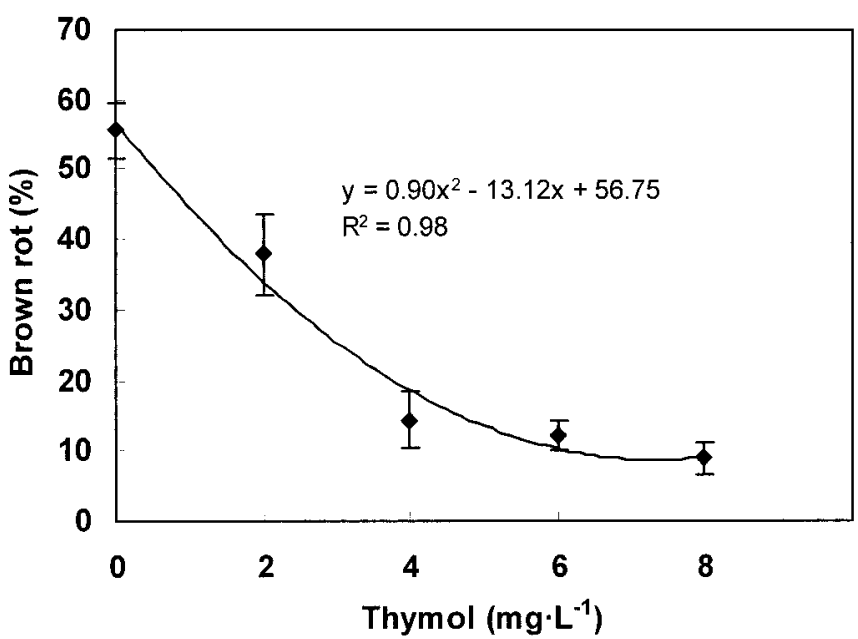

Fig. 6. Brown rot incidence of wounds of 'Veeblue' plums after they were inoculated with Monilinia fructicola, fumigated with 2, 4, 6, or $8 \mathrm{mg} \cdot \mathrm{L}^{-1}$ thymol for $20 \mathrm{~min}$, and incubated at $18^{\circ} \mathrm{C}$ for $7 \mathrm{~d}$. Vertical bars indicate standard errors.
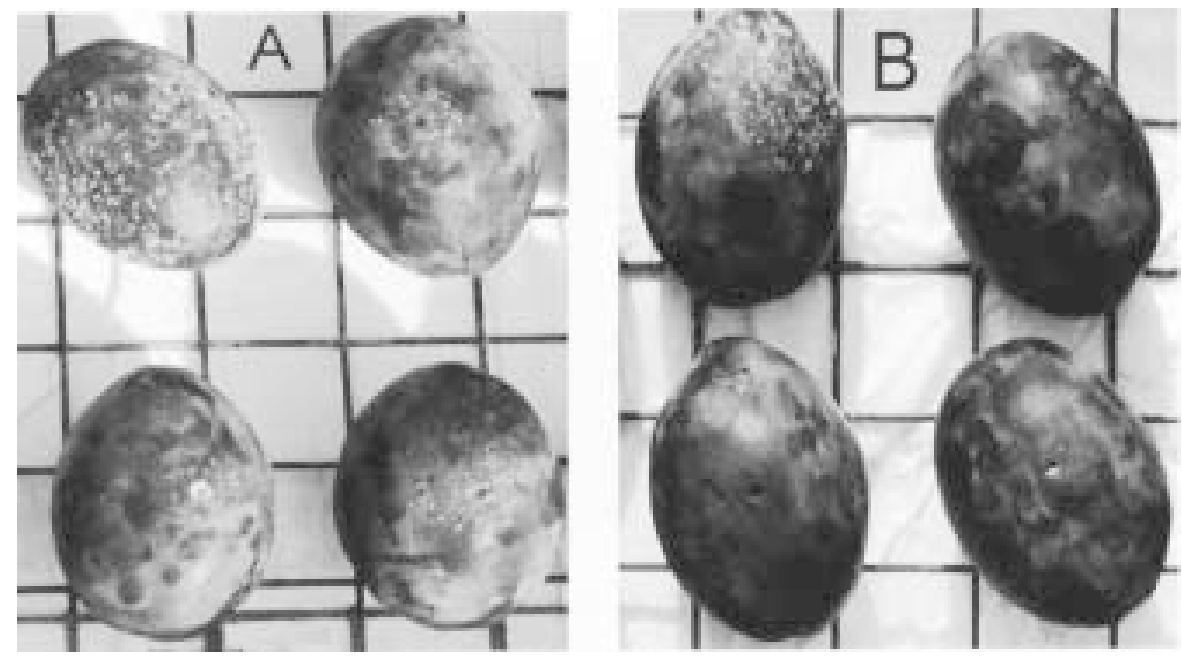

Fig. 7. Brown rot decay on plums inoculated with Monilinia fructicola: (A) fruit without fumigation with thymol; and (B) fruit fumigated with thymol at $8 \mathrm{mg} \cdot \mathrm{L}^{-1}$ for $20 \mathrm{~min}$. The fruit were wounded, inoculated with $20 \mu \mathrm{L}$ of Monilinia fructicola in a water suspension containing $1.0 \times 10^{4}$ conidia/mL, fumigated with $8 \mathrm{mg} \cdot \mathrm{L}^{-1}$ thymol, and incubated at $18^{\circ} \mathrm{C}$ for $7 \mathrm{~d}$.

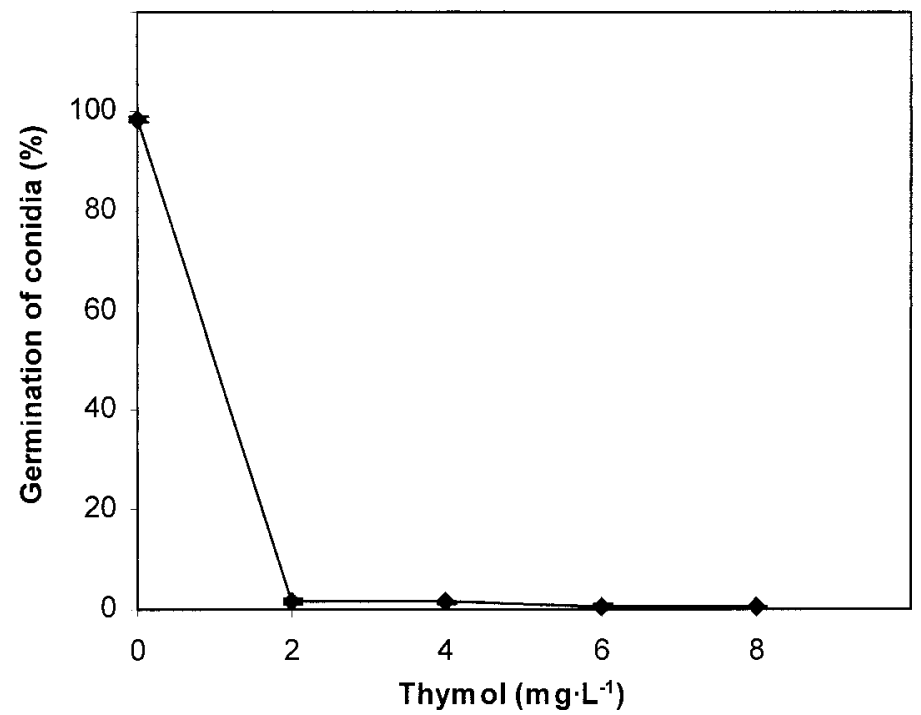

Fig. 8. Germination of Monilinia fructicola conidia scraped from diseased apricots fumigated with 2, 4, 6 , or $8 \mathrm{mg} \cdot \mathrm{L}^{-1}$ thymol. Vertical bars indicate standard errors. 

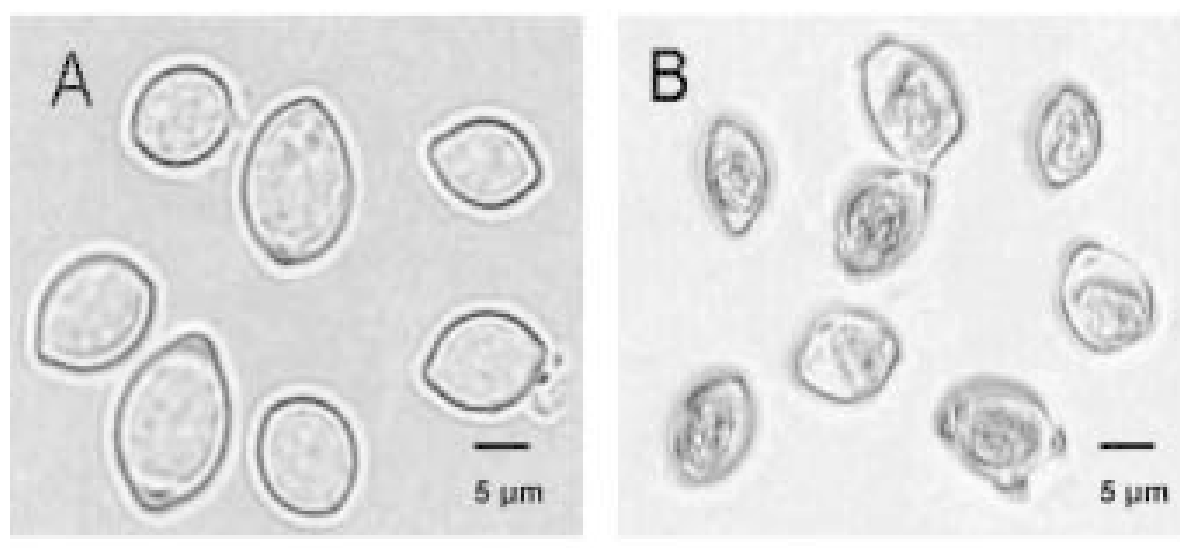

Fig. 9. Morphology and internal structure of conidia collected from Monilinia fructicola infected apricots: (A) conidia from apricots that were not fumigated with thymol; and (B) conidia from apricots that were fumigated with thymol at $8 \mathrm{mg} \cdot \mathrm{L}^{-1}$.

tributes and sensory rating. 'Harglow' apricots fumigated with 6 or $7 \mathrm{mg} \cdot \mathrm{L}^{-1}$ of thymol were firmer than fruits fumigated with lower concentrations (Table 2). Total soluble solids and titratable acidity of thymol-treated apricots were similar. Surface browning, a symptom of phytotoxicity, was observed on all thymol-treated apricots, and the severity of surface browning increased as the thymol concentration increased.

Firmness and titratable acidity of 'Violette' plums fumigated with thymol or acetic acid were similar (Table 3). Plums fumigated with thymol had a higher level of total soluble solids than the non-thymol control samples, but were not different from the fruit fumigated with acetic acid. Plums fumigated with $2 \mathrm{mg} \cdot \mathrm{L}^{-}$ ${ }^{1}$ of thymol had more total soluble solids than the fruits fumigated with 4 or $8 \mathrm{mg} \cdot \mathrm{L}^{-1}$ of thymol. Fumigation with thymol did not affect the quality attributes of firmness, total soluble solids, and titratable acidity of 'Veeblue' plums (data not shown). Fumigation with thymol at concentrations of $2,4,6$, and $8 \mathrm{mg} \cdot \mathrm{L}^{-1}$ also did not affect the sensory ratings such as integrity, color, flavor, and texture for 'Veeblue' plums (data not shown). Thymol fumigation treatments did not cause any discoloration or phytotoxicity on the plums.

\section{Discussion}

The effects of thymol and acetic acid fumigation on postharvest gray mold rot of sweet

Table 2. Quality attributes of 'Harglow' apricots inoculated with conidia of Monilinia fructicola, fumigated with thymol, and stored at $10{ }^{\circ} \mathrm{C}$ for $8 \mathrm{~d}$.

\begin{tabular}{lcccc}
\hline \hline $\begin{array}{l}\text { Thymol } \\
\left(\mathrm{mg} \cdot \mathrm{L}^{-1}\right)\end{array}$ & $\begin{array}{c}\text { Firmness } \\
(\mathrm{g})\end{array}$ & $\begin{array}{c}\text { Total } \\
\text { soluble solids }(\%)\end{array}$ & $\begin{array}{c}\text { Titratable } \\
\text { acidity }(\%)\end{array}$ & $\begin{array}{c}\text { Surface } \\
\text { browning }(\%)\end{array}$ \\
\hline 0 & $20.1 \mathrm{~b}^{\mathrm{z}}$ & 14.8 & 0.80 & $0.0 \mathrm{c}$ \\
3 & $19.9 \mathrm{~b}$ & 15.1 & 0.78 & $18.8 \mathrm{~b}$ \\
4 & $21.3 \mathrm{~b}$ & 15.4 & 0.75 & $25.7 \mathrm{~b}$ \\
5 & $22.3 \mathrm{~b}$ & 15.2 & 0.75 & $42.4 \mathrm{a}$ \\
6 & $25.4 \mathrm{a}$ & 15.4 & 0.75 & $40.2 \mathrm{a}$ \\
7 & $25.1 \mathrm{a}$ & 15.6 & 0.73 & $43.0 \mathrm{a}$ \\
Significance & $* *$ & NS & NS & $* *$
\end{tabular}

${ }^{\mathrm{z}}$ Means within a column by the same letter are not significantly different at $P \quad 0.05$ according to Duncan's multiple range test.

ns, ** Nonsignificant or significant at $P \quad 0.01$. cherries (Prunus avium L.) by Botrytis cinerea have been investigated previously (Chu et al., 1999). This study provides further information on the effect of thymol and acetic acid vapor on M. fructicola and postharvest brown rot of apricots and plums. The brown rot incidences of $M$. fructicola inoculated fruits of both apricots and plums were reduced by thymol or acetic acid fumigation. Thymol vapor greatly inhibited mycelial growth of $M$. fructicola and retarded germination of $M$. fructicola conidia on apricot fruit. The fact that $>95 \%$ of the fumigated conidia lost their ability to germinate indicated that the effect of thymol vapor on the conidia of $M$. fructicola was fatal rather than being temporarily inhibitory. Thymol vapor affected morphological and internal structure of fumigated conidia, causing shrunken shapes and collapsed protoplasts. This strong inhibition of $M$. fructicola probably resulted in the control of brown rot.

Both thymol and acetic acid controlled brown rot symptoms in apricots and plums. Acetic acid may be an effective fumigant for commercial use on fruits, as shown by this study and other investigations (Chu et al., 1999, 2001; Sholberg, 1998; Sholberg et al., 1996). Special care, however, should be taken when using glacial acetic acid because it has a pungent odor, burns the skin, and causes eye irritation. The use of vinegar is much safer and still effective (Sholberg et al., 2000). In this study, thymol was more effective than acetic acid for controlling brown rot symptoms on apricots if both were applied at similar concentrations, but thymol caused greater phytotoxicity, as indicated by surface browning. However, on plums, thymol reduced the incidence of brown rot symptoms without causing any fruit surface browning.

Thymol is an essential oil from thyme (Thymus sp.) and has been used as a medicinal drug, food preserve, and beverage ingredient (Jain, 1985; Mansour et al., 1986). Thymol may be safely used as a postharvest treatment for a variety of fruits. The use of thymol on fresh-market apricots may be limited since appearance is a critical component for fresh fruits, and thymol caused surface browning on apricots. However, thymol fumigation may be recommended for the control of postharvest decay of apricots being processed for foods such as jam, where appearance is not a concern. Experimental data from this study shows that thymol fumigation on plums at a relatively low concentration, such as 2 or $4 \mathrm{mg} \cdot \mathrm{L}^{-1}$, can greatly reduce postharvest decay without causing any phytotoxicity. Large-scale evaluations are needed before thymol can be considered for commercial use.

The U.S. Food and Drug Administration lists thymol, thymol essential oil, and thyme (spice) as foods for human consumption, as well as food additives. The U.S. Environmental Protection Agency (EPA) considers them "Generally Recognized as Safe" (EPA-738-F93-010). Thymol was initially registered as a pesticide in the United States in 1964. Currently, five end-use pesticide products containing the active ingredient thymol are registered. The conditions of re-registration must be fulfilled and required data must be submitted to EPA. At the present time, EPA is not aware of any adverse effects of thymol to humans or the environment when it is used in a manner prescribed by product labeling.

\section{Literature Cited}

Adaskaveg, J.E. and T.J. Michailides. 1996. Cancellation of postharvest use of Rovral 50WP on stone fruit crops and other label changes of the fungicide. Cent. Valley Postharvest Nws1. 5:910.

Arras, G., M. Agabbio, A. Piga, and G. D'Hallewin. 1995. Fungicide effect of volatile compounds of Thymus capitatus essential oil. Acta Hort. 379:593-600.

Table 3. Quality attributes of 'Violette' plums inoculated with conidia of Monilinia fructicola, fumigated with thymol or acetic acid, and stored at $18{ }^{\circ} \mathrm{C}$ for $7 \mathrm{~d}$.

\begin{tabular}{lccc}
\hline \hline Treatment & $\begin{array}{c}\text { Firmness } \\
(\mathrm{g})\end{array}$ & $\begin{array}{c}\text { Total soluble } \\
\text { solids }(\%)\end{array}$ & $\begin{array}{c}\text { Titratable } \\
\text { acidity }(\%)\end{array}$ \\
\hline Control & 76.8 & $11.3 \mathrm{c}^{2}$ & 0.82 \\
Thymol $2 \mathrm{mg} \cdot \mathrm{L}^{-1}$ & 70.4 & $12.9 \mathrm{a}$ & 0.78 \\
Thymol $4 \mathrm{mg} \cdot \mathrm{L}^{-1}$ & 71.5 & $12.0 \mathrm{~b}$ & 0.79 \\
Thymol $8 \mathrm{mg} \cdot \mathrm{L}^{-1}$ & 78.9 & $12.3 \mathrm{~b}$ & 0.77 \\
Acetic acid $2 \mathrm{mg} \cdot \mathrm{L}^{-1}$ & 73.3 & $11.7 \mathrm{bc}$ & 0.78 \\
Acetic acid $4 \mathrm{mg} \cdot \mathrm{L}^{-1}$ & 70.9 & $11.8 \mathrm{bc}$ & 0.76 \\
Acetic acid $8 \mathrm{mg} \cdot \mathrm{L}^{-1}$ & 77.2 & $11.9 \mathrm{bc}$ & 0.78 \\
Significance & $\mathrm{NS}$ & $* *$ & $\mathrm{NS}$ \\
\hline
\end{tabular}

${ }^{2}$ Means within a column by the same letter are not significantly different at $P \quad 0.05$ according to Duncan's multiple range test.

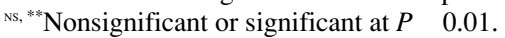


Biggs, A.R., M.M. El-Kholi, S. El-Neshawy, and R. Nickerson. 1997. Effects of calcium salts on growth, polygalacturonase activity, and infection of peach fruit by Monilinia fructicola. Plant Dis. 81:399-403.

Bosch, J.R., A.R. Gonzalez, J.K. Mitchell, and J.M. Aselage. 1992. Quality change in peach puree by brown rot (Monilinia fructicola) and biological control agents. J. Food Qual. 15:449458.

Chu, C.L., W.T.Liu, and T.Zhou. 2001. Fumigation of sweet cherries with thymol and acetic acid to reduce postharvest brown rot and blue mold rot. Fruits 56:123-130.

Chu, C.L., W.T. Liu, T. Zhou, and R. Tsao. 1999. Control of postharvest gray mold rot of modified atmosphere packaged sweet cherries by fumigation with thymol and acetic acid. Can. J. Plant Sci. 79:685-689.

De Vries-Paterson, R.M., A.L. Jones, and A.C. Cameron. 1991. Fungistatic effects of carbon dioxide in a package environment on the decay of Michigan sweet cherries by Monilinia fructicola. Plant Dis. 75:943-946.

Dixit, S.N., H. Chandra, R. Tiwar, and V. Dixit. 1995. Development of botanical fungicide against blue mould of mandarins. J. Stored Prod. Res. 31:165-172.

El Ghaouth, A., C.L. Wilson, and M.E. Wisniewski. 1995. Sugar analogs as potential fungicides for the postharvest pathogens of apple and peach. Plant Dis. 79:254-258.

Falconi, C.J. and K. Mendgen. 1994. Epiphytic fungi on apple leaves and their value for control of the postharvest pathogens Botrytis cinerea, Monilinia frutigena and Penicillium expansum. J. Plant Dis. Prot. 101:38-47.

Feliciano, A., A.J. Feliciano, J. Vendrusculo, J.E. Adaskaveg, and J.M. Ogawa. 1992. Efficacy of ethanol in postharvest benomyl-DCNA treatments for control of brown rot of peach. Plant Dis. 76:226-229.

Harvey, J.M., W.L. Smith, Jr., and J. Kaufman. 1972. Market diseases of stone fruits: cherries, peaches, nectarines, apricots and plums. U.S. Dept. Agr. Agr. Hdbk. 414.

Hong, C., T.J. Michailides, and B.A. Holtz. 1998. Effects of wounding, inoculum density, and biological control agents on postharvest brown rot of stone fruits. Plant Dis. 82:1210-1216.
Jain, S.K. 1985. Medicinal plants. Natl. Book Trust, New Delhi.

Jerome, S.M.R. 1958. Brown rot of stone fruit: latent contamination in relation to spread of the disease. J. Austral. Inst. Agr. Sci. 24:132-140.

Mansour, F., U. Ravid, and E. Putievsky. 1986. Studies of essential oils isolated from 14 species of Labiatae on the carimine spider mint, Tetranychus cinnabarinus. Phytoparasitica 14:137-142.

Margosan, D.A., J.L. Smilanick, G.F. Simmons, and D.J. Henson. 1997. Combination of hot water and ethanol to control postharvest decay of peaches and nectarines. Plant Dis. 81:14051409.

Mattheis, J.P. and R.G. Roberts. 1993. Fumigation of sweet cherry (Prunus avium 'Bing') fruit with low molecular weight aldehydes for postharvest decay control. Plant Dis. 77:810-814.

Michailides, T.J. and D.P. Morgan. 1997. Influence of fruit-to-fruit contact on the susceptibility of French prune to infection by Monilinia fructicola. Plant Dis. 81:1416-1424.

Mihaliak, C.A., J. Gershenzo, and R. Croteau. 1991. Lack of rapid monoterpene turnover in rooted plants, implications for theories of plant chemical defense. Oecologia 87:373-376.

Mishra, A.K. 1994. Evaluation of some essential oils for their toxicity against fungi causing deterioration of stored food commodities. Appl. Environ. Microbiol. 60:1101-1105.

Moyls, A.L., P.L. Sholberg, and A.P. Gaunce. 1996. Modified-atmosphere packaging of grapes and strawberries fumigated with acetic acid. HortScience 31:414-416.

Sholberg, P.L. 1998. Fumigation of fruit with shortchain organic acids to reduce the potential of postharvest decay. Plant Dis. 82:689-693.

Sholberg, P.L. and A.P. Gaunce. 1995. Fumigation of fruit with acetic acid to prevent postharvest decay. HortScience 30:1271-1275.

Sholberg, P.L., and A.P. Gaunce. 1996. Fumigation of stone fruit with acetic acid to control postharvest decay. Crop Prot. 15:681-686.

Sholberg, P.L., P. Haag, R. Hocking, and K. Bedford. 2000 . The use of vinegar vapor to reduce postharvest decay of harvested fruit. HortScience 35:898-903.

Sholberg, P.L., A.G. Reynolds, and A.P. Gaunce. 1996. Fumigation of table grapes with acetic acid to prevent postharvest decay. Plant Dis. 80:1425-1428.

Smid, E.J., Y. Witte, O. de Vrees, and L.G.M. Gorris. 1994. Use of secondary plant metabolites for the control of postharvest fungal diseases on flower bulbs. Acta Hort. 368:523-530.

Smilanick, J.L. 1994. Strategies for the isolation and testing of biocontrol agents, p. 25-41. In: C.L. Wilson and M.E. Wisniewski (eds.). Biological control of postharvest diseases theory and practice. CRC Press, London.

Smilanick, J.L., R. Denis-Arrue, J.R. Bosch, A.R. Gonzalez, D. Henson, and W.J. Janisiewicz. 1993. Control of postharvest brown rot of nectarines and peaches by Pseudomonas species. Crop Prot. 12:513-520.

Snowdon, A.L. 1990. Post-harvest diseases and disorders of fruit and vegetables. Vol. 1, Gen. Intro. CRC Press, Boca Raton, Fla.

Stevens, C., C.L. Wilson, J.Y. Lu, V.A. Khan, E. Chalutz, S. Droby, M.K. Kabwe, Z. Haung, O. Adeyeye, and L.P. Pusey. 1996. Plant hormesis induced by ultraviolet light-C for controlling postharvest diseases of tree fruits. Crop Prot. 15:129-134.

Tiwari, R., D.N. Mishra, and P.S. Upadhyaya. 1988. Efficacy of some plant volatiles for the control of black-mould of onion caused by Aspergillus niger Van Tiegh during storage. Natl. Acad. Sci. Lett. 11:345-347.

Tsao, R. and T. Zhou. 2000. Antifungal activity of monoterpenoids against postharvest pathogens Botrytis cinerea and Monilinia fructicola. J. Essential Oil Res. 12:113-121.

Wells, J.M., J.E. Butterfield, and M.J. Ceponis. 1994. Diseases, physiological disorders, and injuries of plums marked in metropolitan New York. Plant Dis. 78:642-644.

Wilson, C.L. and M. Wisniewski. 1989. Biological control of postharvest diseases. Ann. Rev. Phytopathol. 27:425-441.

Wilson, C.L., M.E. Wisniewski, C.L. Biles, R. McLaughlin, E. Chalutz, and S. Droby. 1991. Biological control of post-harvest diseases of fruits and vegetables: Alternatives to synthetic fungicides. Crop Prot. 10:172-177.

Zhou, T., J. Northover, and K. Schneider. 1999. Biological control of postharvest diseases of peach with phyllosphere isolates of Pseudomonas syringae. Can. J. Plant Pathol. 21:375-381. 